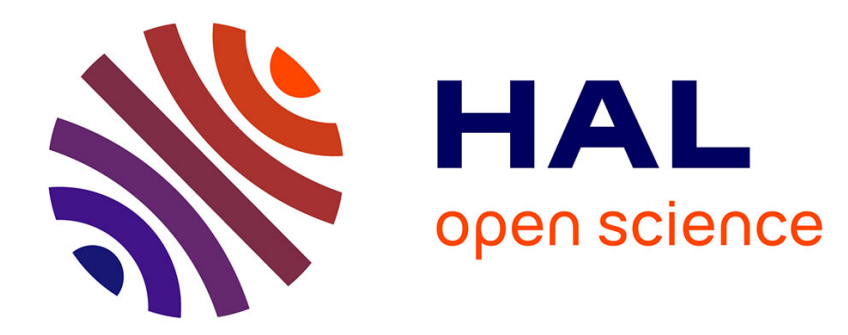

\title{
A Visionary Pioneer of Parasite Ecology and Evolution Samuel Alizon
}

\section{To cite this version:}

Samuel Alizon. A Visionary Pioneer of Parasite Ecology and Evolution. American Naturalist, 2016, 187 (6), pp.ii-iii. 10.1086/686526 . hal-01567905

\section{HAL Id: hal-01567905 \\ https://hal.science/hal-01567905}

Submitted on 5 May 2018

HAL is a multi-disciplinary open access archive for the deposit and dissemination of scientific research documents, whether they are published or not. The documents may come from teaching and research institutions in France or abroad, or from public or private research centers.
L'archive ouverte pluridisciplinaire HAL, est destinée au dépôt et à la diffusion de documents scientifiques de niveau recherche, publiés ou non, émanant des établissements d'enseignement et de recherche français ou étrangers, des laboratoires publics ou privés. 
COUNTDOWN TO 150

\title{
A Visionary Pioneer of Parasite Ecology and Evolution
}

\author{
Samuel Alizon*
}

Laboratoire Maladies Infectieuses et Vecteurs: Ecologie, Génétique, Evolution et Contrôle (Unité Mixte de Recherche CNRS 5290, Institut de Recherche pour le Développement 224, Université de Montpellier), 911 Avenue Agropolis, BP 64501, 34394 Montpellier Cedex 5, France

The first American Naturalist appeared in March 1867. In a countdown to the 150th anniversary, the editors have solicited short commentaries on articles from the past that deserve a second look.

A combination of ecology and evolutionary biology has been one of the hallmarks of The American Naturalist since the introductory comments in its first issue, in which the editors placed the new "magazine" in the footsteps of Darwin (only 8 years after the publication of On the Origin of Species). Singling out a single article to celebrate the 150th anniversary of the journal is no easy task. However, for several reasons, I think that "Parasitic Bacteria and their Relation to Saprophytes," by Theobald Smith (1887), nicely captures its spirit. First, this article is an illustration of how interwoven ecology and evolution are and why both need to be studied simultaneously. Second is the personality of the author, who was among the first to import evolutionary thinking into human and veterinary medicine. Third, more than a century later, this article, while rarely read, is still inspiring.

Theobald Smith (1859-1934) may not be familiar to today's audience of The American Naturalist (he surely was not when the article was published). Along with Pasteur, Koch, Lister, and their disciples in Europe, Smith was one of the founding fathers of microbiology (P. F. Clark, 1959, "Theobald Smith, Student of Disease (1859-1934)," Journal of the History of Medicine and Allied Sciences 14:490-514). Smith's broad knowledge of the bacterial world was acquired from reading and from repeating Pasteur's and Koch's experiments. Smith's professional trajectory is also unusual because, as a gifted student in the Albany, New York, public schools, he was primarily attracted to mathematics and teaching. According to Clark, Smith would say, not too seriously, that "his first choice of occupation would have been a tramp, second a musician or mathematician" (p. 510). After gradu-

* E-mail: samuel.alizon@cnrs.fr.

Am. Nat. 2016. Vol. 187, pp. ii-iii. (C) 2016 by The University of Chicago. 0003-0147/2016/18706-56837\$15.00. All rights reserved. DOI: $10.1086 / 686526$ ating from Albany Medical School in 1884, he realized that, like Darwin, he was not attracted by medical practice and went to work for the Bureau of Animal Industry in Washington for 5 years. It is during this time that he wrote his sole American Naturalist contribution.

Unlike modern articles in this journal, this contribution presented theories with no data or mathematical models to back them up. Its main thesis was that parasitic (and, hence, virulent) bacteria originate from (avirulent) saprophytic bacteria and, more generally, that virulence evolution is driven by the parasite's life cycle. Smith's hypotheses were carefully supported by empirical data on human and animal parasites, although tracking their sources is complicated because he does not cite other articles or books.

The existence of microbial evolution as a research field in the 19th century may come as a surprise to many. And yet recent scholarly work has shown that Darwin himself had thought about integrating microbes into his theories (M. A. O’Malley, 2009, "What Did Darwin Say about Microbes, and How Did Microbiology Respond?," Trends in Microbiology 17:341-347). However, some leaders of the neo-Darwinian synthesis tended to dismiss microbial work that occurred prior to the discovery of DNA due to its "Lamarckian flavor," as Theodosius Dobzhansky put it. This is undoubtedly true of many microbiology studies at the time but not of those of Smith, who explicitly invokes "natural selection."

When reading Smith's article, what comes to mind is the Latin proverb "Nihil novi sub sole" (Nothing new under the sun). Already in the second paragraph, he mentions, in passing, that different bacteria are found in different areas of the digestive tract, meaning that gut microbiota community ecology was born with microbiology. Even its applications were already envisaged, as he writes that curing digestive derangements will come only with a better understanding of the bacteriology of the digestive tract. Furthermore, as in Origin, the only figure in the article is of a phylogeny. The point Smith wanted to convey was that bacteria can evolve from true saprophytes to obligatory parasites: he argues that "all pathogenic bacteria were derived by a process of natural selection from the innumerable harmless species everywhere 
peopling the air, the soil, and the water" (p. 4). Phylogenetic analyses of Mycobacterium tuberculosis conducted 118 years later seem to prove him right, because bacteria from this complex belong to a group of slow-growing mycobacteria, which themselves derive from rapidly growing mycobacteria that are mostly saprophytic (G. M. Devulder, M. Pérouse de Montclos, and J. P. Flandrois, 2005, “A Multigene Approach to Phylogenetic Analysis Using the Genus Mycobacterium as a Model," International Journal of Systematic and Evolutionary Microbiology 55:293-302).

Since the study of microbial evolution did exist by the 1880 s, one could be tempted to see this article as a mere summary of the state of the art. Based on my expertise in virulence evolution, however, I do not think this is the case. Several excerpts show that Smith was ahead of his time. First, it is striking to observe how he tackles the problem of why some bacteria are virulent with a naturalist's eye, an approach that was (and, some might argue, still is) quite original. For Smith, understanding the parasite's life cycle was key to answering this question. Second, in contrast with the schools of Pasteur and Koch, who viewed microbes as being either virulent (if they cause disease) or avirulent, Smith envisioned a virulence continuum. Even more ahead of his time, he seemed to think that the environment in which a microbe finds itself affects its level of virulence: "Now and then bacteria which carry on a harmless existence in one place may become very virulent in others" (p. 2). Perhaps the explanation for the relative oblivion of this article is that, until recently, the field lacked the tools to prove that Smith's intuitions were right. For instance, the claim that microbes can be classified as pathogens or nonpathogens has been challenged by progress in sequencing, which is revealing that some microbes typically considered to be pathogens can be present without causing disease, whereas other microbes thought to be commensals can cause disease.

In evolutionary ecology, Smith is probably best known for his "law of declining virulence," which postulates that, given enough time, a host-parasite interaction will evolve to avirulence (P. O. Méthot, 2012, "Why Do Parasites Harm Their Host? On the Origin and Legacy of Theobald Smith's 'Law of Declining Virulence'-1900-1980," History and Philosophy of the Life Sciences 34:561-601). Although this idea has been dismissed by some as common wisdom, it is important to recall that, at the time, it was completely novel. It opened up the possibility of a genuine ecological and evolutionary understanding of infectious diseases. When Smith writes that "it is for the interest of the more strictly parasitic forms that their host live as long as possible" (p. 7), this is perhaps the first occurrence of a theory that still prevails among clinicians or other disease experts. If we read even more carefully, we can see that Smith was already aware of the limitations of his theory: he adds that it may not apply if the microbe can also live outside its host. For instance, using anthrax as an example, he argues that the fact that the parasite cannot complete its life cycle within the host (anthrax requires exposure to air for the sporulation stage) can account for the maintenance of its high virulence.

Overall, although Smith wrote this article when he was a 28-year-old medical doctor working in an applied office, his originality and flair already transpire from every page, and one can find foreshadowing of his future research. Identifying the agents causing disease through bacteriological methods was insufficient for him; he also sought to understand why they were or were not virulent. In a way, he was already one step ahead of many current research projects that solely aim at identifying new bacteria in various environments. He also realized that to understand human and animal diseases, one also has to look outside the infected host. This is a point recently taken up by the One Health perspective, which argues that understanding animal health and the environment will help improve human health. It is probably no coincidence that a few years after publication of this article, Smith played a key role in demonstrating that ticks can act as a vector of Texas cattle fever. Grasping the importance of parasite ecology not only to understand and fight infections (which was already visionary) but also to understand their evolution in nature places Smith as an unappreciated founder of evolutionary approaches to health and disease.

To conclude, celebrating this neglected contribution after 129 years is also a way to honour Smith's idea of research, which he summarized in the following way 45 years later:

We must not be discouraged if the products of our labor are not read or even known to exist. The joy of research must be found in the doing since every other harvest is uncertain and even the prizes do not always go to the discoveries to which we would assign them. Research has deserted the individual and entered the group. The individual worker finds the problem too large, not too difficult. He must learn to work with others. (Quoted in Clark 1959, p. 511)

\section{In The American Naturalist}

Smith, Theobald. 1887. Parasitic bacteria and their relation to saprophytes. American Naturalist 21:1-9. 